PROCESOS

ReVIsTA ECUATORIANA de HISTORIA

\title{
Algunos apuntes para una estética literaria según Juan León Mera: entre romanticismo y neoclasicismo
}

Notes for literary aesthetics according to Juan León Mera: Between Romanticism and Neoclassicism

Apontamentos para uma estética literária segundo Juan León Mera: entre romanticismo e neoclassicismo

Xavier Puig Peñalosa

Universidad del País Vasco/EHU (España) xavier.puig@ehu.eus

DOI: http: / / dx.doi.org/10.29078/rp.v0i47.675

Fecha de presentación: 25 de marzo de 2018 Fecha de aceptación: 20 de mayo de 2018

Artículo de investigación 
RESUMEN

El artículo analiza las ideas estético-literarias de Juan León Mera, quien se propuso instituir un canon para la literatura ecuatoriana de su época. Esta propuesta halla su origen tanto en postulados de la estética romántica como en los pertenecientes a la poética neoclásica. Este trabajo aporta dilucidando cuáles categorías de ambas corrientes

fueron usadas por Mera en su obra ensayística y epistolar, como fundamento de su propuesta sincrética.

Palabras clave: Ecuador, siglo XIX, Juan León Mera, literatura ecuatoriana, canon, estética, poesía, romanticismo, neoclasicismo.

ABSTRACT

The article examines Juan León Mera's ideas on literary aesthetics and how he proposed establishing a canon for the Ecuadorian literature of his age. This initiative drew from both the postulates of the aesthetics of Romanticism and those belonging to Neoclassical poetry. The present article elucidates which categories of both movements were used by Mera in his essays and correspondence, as the basis for his syncretic approach.

Keywords: Ecuador, nineteenth century, Juan León Mera, Ecuadorian literature, canon, aesthetics, poetry, Romanticism, Neoclassicism.

RESUMO

O artigo analisa as ideias estéticas e literárias do Juan León Mera, quem se propôs estabelecer um cânone para a literatura equatoriana da sua época. Esta proposta teve suas origens na estética romântica, e na poética neoclássica. $\mathrm{O}$ artigo esclarece quais foram as categorias de ambas correntes literárias que foram incorporadas por Mera nos seus ensaios e na sua correspondência pessoal, como alicerces daquela proposta sincrética.

Palavras chave: Equador, século XIX, Juan León Mera, literatura equatoriana, cânon, estética, poesia, romanticismo, neoclassicismo. 


\section{INTRODUCCIÓN}

En el contexto de "construcción nacional" que los distintos gobiernos del Ecuador llevan a cabo durante el siglo XIX y, particularmente a partir de la segunda mitad de dicho siglo, es donde se inscribe la producción literaria y ensayística -además de pictórica- de Juan León Mera. De hecho, su admiración por el proyecto nacional de Gabriel García Moreno, especialmente a partir del segundo mandato de este, quedará patente en numerosos escritos del literato. Y es que la concepción estético-literaria de Mera, tanto en su pionera labor crítica respecto a la literatura existente como su propia obra poético-literaria, hallan su finalidad tanto en su pasión creadora como en poder ofrecer un modelo ejemplificante y canónico para una renovada literatura nacional que coadyuvase en ese proyecto de "construcción nacional", integrando tanto a la tradición de la poesía indígena (quichua) seleccionados cantares populares, o la edición de cierta producción literaria hecha por mujeres -por primera vez en el país-, aunque debidamente criticada desde los propios presupuestos poéticos del autor. Y determinante a los efectos de ese propósito será su fundamentación a partir de precisos conceptos y/o categorías (historicistas) de la estética romántica adaptados a la idiosincrasia nacional como, igualmente y desde el punto de vista constructivo-formal, de otros pertenecientes a los postulados de la poética neoclásica, ambos vigentes sincrónicamente en el país. Es decir, Mera propondrá una suerte de sincretismo estético-artístico que sirva de guía conceptual, crítica y creativa para la necesaria renovación de la creación literaria en el país, y que al tiempo contribuya a la construcción de la "nación plural".

A tenor de lo expuesto, será principalmente en sus escritos de carácter más ensayístico, así como en muchas de sus numerosas "Cartas", donde el autor expresará sus ideas estético-literarias y a las que recurriremos analíticamente para poner de relieve ese sincretismo señalado con la finalidad de poder ofrecer, sin ánimo exhaustivo, algunas de las más destacadas claves interpretativas de su pensamiento creativo. 


\section{Historicismo ROMÁNTICO en Juan León Mera}

La recepción del Romanticismo en Ecuador fue bastante tardía, ${ }_{1}^{1}$ resaltando el género literario como el de mayor difusión; no obstante, solo algunos de sus postulados -tamizados por los de la escolástica- ${ }^{2}$ tuvieron verdadera aceptación entre las élites intelectuales del país, principalmente conservadoras, conformando un peculiar sincretismo ${ }^{3}$ en el que se primará todos aquellos aspectos que, de una forma u otra, estén relacionados o puedan servir a la construcción de "lo nacional", es decir, a una conciencia unitaria y homogénea de nación que superase las tendencias centrífugas del acendrado regionalismo imperante, mediante la implementación de unas leyes y un estado centralizador, afines a las ideas de progreso y modernidad europeas, aunque, eso sí, basados en una concepción aristocratizante y patriarcal de la sociedad, y en la que resultaban excluidas de la práctica sociopolítica las clases subalternas. ${ }^{4}$

1. "Los autores ecuatorianos estaban al tanto de las corrientes [estéticas] europeas e incluso en abierto diálogo con sus más conspicuos representantes: Boileau, Verney, Bouhours, [...] en un primer momento; y Buffon, Rousseau, Saint Pierre, Chateaubriand, Hegel, [...] posteriormente". En Carlos Paladines, Sentido y trayectoria del pensamiento ecuatoriano (Quito: Banco Central del Ecuador, 1990), 330. También y en el mismo sentido: "El tema del sentimiento estético, trabajado fundamentalmente durante el siglo XIX (Schelling) muestra que los autores ecuatorianos estaban al tanto de las corrientes europeas". En Pensamiento estético ecuatoriano, estudio introductorio y selección de Daniel Prieto Castillo (Quito: Banco Central del Ecuador / Corporación Editora Nacional, 1986), 35.

2. Paradigma de la influencia escolástica en el romanticismo ecuatoriano sería la tardía obra de Federico González Suárez, Hermosura de la naturaleza y sentimiento estético de ella, con preámbulo del escritor y político conservador-católico español Marcelino Menéndez Pelayo (Madrid: Est. Tipográfico "Sucesores de Rivadeneyra" / Impresores de la Real Casa, 1908), http: / / repositorio.casadelacultura.gob.ec/bitstream/34000/983/1/ FR1-L-000335-Gonzalez-Hermosura.pdf.

3. "Filosóficamente considerados, ni el romanticismo ni el historicismo adquirieron en el Ecuador rigor sistemático, y debe hablarse, más bien, de 'elementos' románticos e historicistas en muchos pensadores de la segunda mitad del siglo XIX [...]. Sin embargo, tanto aquéllos como éstos [románticos e historicistas] son testimonios fehacientes de la influencia segura y persistente de ciertas ideas románticas en el Ecuador". En Pensamiento romántico ecuatoriano, estudio introductorio y selección de Rodolfo Agoglia (Quito: Banco Central del Ecuador / Corporación Editora Nacional, 1988), 48-49.

4. Carlos Paladines, el autor ya citado y a nuestro juicio el más importante en el estudio del Romanticismo ecuatoriano -además de otras corrientes de pensamiento- en su publicación Sentido y trayectoria..., nos informa de las dos fases del movimiento romántico ecuatoriano (1835-1895 y 1895-1925) con sus respectivos matices y/o diferencias, a la par que establece tres tendencias según sus diferentes contenidos programáticos, a saber, la 
Para ello, particular importancia revestirá la resemantización en clave autóctona de los postulados historicistas de Herder y sintetizados en su concepto de Volksgeist como afirmación de lo propio (variedad de usos y costumbres de los pueblos, lenguajes, tradiciones, razas, historia, etc., en relación a las diversas peculiaridades climatológicas y/o geográficas de cada territorio). Y resemantización que, muy especialmente en el caso de la literatura, irá mayormente transida de una fuerte moralidad católico-conservadora y patriótica como vehículo educativo y forjador de la conciencia del "buen ciudadano" y de su "espíritu nacional":

en el caso de que la construcción de la nación no fuera el argumento principal de todas ellas [las novelas analizadas] y no emergiera de ellas hacia el ámbito político, cabe resaltar, de cualquier modo, que todas tienen a la nación como un motivo transversal que les da forma y legitima socialmente $[\ldots]$ los primeros novelistas ecuatorianos estaban interesados en fabular, en inventar historias, solo en la medida en que les permitiera educar y formar a un nuevo lector modelo: el ciudadano ecuatoriano. ${ }^{5}$

Es en este marco estético-conceptual sucintamente expuesto donde se ubica el pensamiento estético de Juan León Mera, ya que aquel supondrá el origen y fundamento para su propia concepción de una literatura y / o poesía americana, como a continuación se expondrá. ${ }^{6}$

No obstante, conviene precisar que antes de elaborar más pormenorizadamente sus concepciones estético-literarias, Juan León Mera ya había hecho gala literariamente de aquellas en su temprano poemario de 1861 titulado $\mathrm{La}$ Virgen del Sol. Leyenda indígena y en el que también figura en su segunda edición (1886) sus Melodías indígenas (1858). Así, y en el "Prólogo" que redactó

conservadora, la liberal-católica y la liberal emergente, "a cada una de las cuales prestó sus servicios el pensamiento romántico" en ambas fases, ya que este "no hizo más que sumarse a las diferentes expresiones del proyecto histórico de la naciente burguesía", es decir, a la creación de un Estado nacional (143 para ambas citas; véase al respecto las pp. 121-257). Véase también "El romanticismo en Ecuador e Hispanoamérica". En Historia de las literaturas del Ecuador. Literatura de la República. 1830-1895, coord. por Diego Araujo Sánchez, 55-70 (Quito: Universidad Andina Simón Bolívar, Sede Ecuador / Corporación Editora Nacional, 2002), y en el mismo volumen los trabajos de Bruno Sáenz Andrade, "La literatura en el período", 71-90, y Susana Aguinaga Zumárraga, "La lírica romántica", 91-124.

5. César Eduardo Carrión Carrión, "La novela ecuatoriana del siglo XIX como relato del surgimiento de la nación (1855-1893)" (tesis de doctorado, Universidad Andina Simón Bolívar, Sede Ecuador, 2016), 51 y 65, http://repositorio.uasb.edu.ec/bitstream/10644/5751/1/TD090-DLLA-Carrion-La\%20novela.pdf.

6. Resulta muy interesante, en este sentido, el trabajo de Catalina León Pesántez, Hispanoamérica y sus paradojas en el ideario filosófico de Juan León Mera (Quito: Universidad Andina Simón Bolívar, Sede Ecuador / Abya-Yala / Corporación Editora Nacional, 2011). 
para dicha edición, enuncia sintéticamente una de las ideas principales de su concepción para una nueva poesía americana:

Para escribir las Melodías procuré hacer lo mismo que para escribir la Leyenda [indígena, es decir, La Virgen del Sol]; esto es, trasladarme con la mente y el corazón á los tiempos en que cantaban los haravicos ó poetas indios, y, fingiéndome uno de ellos penetrar los sentimientos de la raza indígena plantada y desarrollada en las mesetas de los Andes ecuatorianos, y estudiar sus pensamientos, creencias, costumbres é historia: he intentado, pues, hacerme también indio y olvidar la civilización y más condicionantes de la vida moderna predominantes en la sociedad americana [...] [ello] ha servido á lo menos para añadir á nuestra literatura unas pocas páginas nuevas y originales. ${ }^{7}$

Es decir, Mera reivindica un conocimiento de un pasado ancestral indígena como marco y contenido históricos para una nueva poesía que permita desligarse mentalmente de un presente no deseado y que, al tiempo, aporte originalidad a la creación poemática. Además, esta apelación a la cultura indígena será constante en la obra de Mera, pues no solo permite establecer una continuidad entre un pasado y el presente, sino, y quizá sea lo más importante, integrar a la nación (ecuatoriana) a esa etnia respetando su propia cultura. A este tenor y dentro de la amplísima producción literaria, ensayística, divulgativa, periodística y epistolar de Juan León Mera, ${ }^{8}$ resultará especialmente relevante para la historia de las ideas literarias y la propia literatura ecuatoriana dada su decisiva influencia en toda una amplia generación de poetas nacionales, su ensayo titulado " ¿Es posible dar un carácter nuevo y original a la poesía sudamericana?", perteneciente a su extenso libro

7. "Prólogo". En La Virgen del Sol. Leyenda. Melodías indígenas, t. I, XIV-XV (Barcelona: Timbre Imperial, Sección Tipográfica del Crédito Catalán, 1887), https: / / archive.org/ stream/lavrgendelsolle01meragoog\#page/n18/mode/2up.

8. La primera recopilación bibliográfica de la obra de Juan León Mera y a partir de la que se han basado las ulteriores, corresponde a la ya "clásica" de Carlos A. Rolando, Don Juan León Mera 1832-1932 (Guayaquil: Imprenta i Talleres Municipales, 1932), http: / / repositorio.flacsoandes.edu.ec/ bitstream / 10469/12547 / 2 / FBNCCE-Rolando-6918-PUBCOM.pdf. Posteriormente, se publicaría otra "Bibliografía de Juan León Mera” a cargo de José Vera. En Juan León Mera. Antología esencial, estudio introductorio, selección de textos, notas y edición de Xavier Michelena, 405-427 (Quito: Banco Central del Ecuador / AbyaYala, 1994), y la de Wilson Vega y Vega, "Corpus bibliográfico de don Juan León Mera". En Juan León Mera. Una visión actual, ed. por Julio Pazos Barrera, 163-178. (Quito: Pontificia Universidad Católica del Ecuador / Universidad Andina Simón Bolívar, Sede Ecuador / Corporación Editora Nacional, 1994). Y sobre la obra en general de Juan León Mera, véase la bibliografía aportada en http: / / www.cervantesvirtual.com/portales / juan_leon_ mera/su_obra_bibliografia/. 
Ojeada histórico-crítica sobre la poesía ecuatoriana desde su época más remota hasta nuestros dias. ${ }^{9}$

Dicho libro supone el primer texto de crítica literaria en Ecuador, ya que además de desarrollar una diacronía histórico-crítica sobre las obras de los poetas ecuatorianos más antiguos hasta los de la propia contemporaneidad del autor, ofreciendo así un conocimiento sobre aquellos, pretende así mismo "contribuir de alguna manera á la formacion del buen gusto entre nuestros jóvenes compatriotas dedicados al culto de las musas". ${ }^{10}$

Es decir, la finalidad que guía a este escrito responde a la crítica y superación de la mayormente imperante literatura basada en la imitación de los modelos europeos -especialmente franceses $-{ }^{11}$ en lo que se refiere a sus contenidos narrativos (temáticas greco-latinas), así como a su deficiente elaboración formal, ${ }^{12}$ ya que ambas cuestiones resultan totalmente ajenas e impiden una auténtica creación artística que responda a lo "americano", a saber y como a continuación se desarrollará, a una (nueva) literatura americana que refleje el carácter y el "ser" de estos pueblos ("americanismo"), y que al tiempo sirva como educación moral, puesto que "la poesía ha sido descubierta indudablemente para encaminar el alma hácia el bien; imposible que el Criador la hubiese puesto en sus obras con otro objeto". ${ }^{13}$ Además, cabe añadir a lo señalado la falta de verdaderos estudios literarios en el país, base indispensable para formar crítica y creativamente a futuros literatos. ${ }^{14}$

9. La primera edición de esta obra es la correspondiente al año 1868 (Quito: Imprenta de J. Pablo Sanz), http:/ / repositorio.casadelacultura.gob.ec/handle/34000/1223. Años más tarde -en 1893-, se imprimiría una segunda edición (Barcelona: Imprenta y Litografía de José Cunill Sala), que incorpora "Nuevos Apéndices", http: / / repositorio.casadelacultura.gob.ec/handle/34000/1220.

10. "Prólogo". En Ojeada histórico-crítica..., I.

11. "Después de establecida la república en suelo americano, mudó de carácter la poesía, mas no mejoró: de amanerada y viciosa á la española vino á ser amanerada y viciosa á la francesa ; la influencia ultramarina cambió de armas, si puede decirse, pero no dejó de atacarnos ni de triunfar y ser preponderante. Nuestros poetas cedieron á ella", en "Vicios principales de la poesía americana en la actualidad, especialmente en el Ecuador". Ibíd., 411.

12. Por ejemplo, Mera criticará en el capítulo citado en la nota anterior, a una parte considerable de la producción poética de su tiempo en los siguientes términos: vacua en el contenido, simple en la composición, amanerada en la imitación, fingida en los estados de ánimo, insulsa y chabacana en la expresión al tiempo que llena de hipérboles y verbosidad, cuando no impía, etc.

13. "Vicios principales de la poesía americana en la actualidad, especialmente en el Ecuador". En Ojeada histórico-crítica..., 428.

14. Posteriormente y entre otras cuestiones, Mera insistirá nuevamente sobre los motivos y finalidades que le impulsaron a escribir la Ojeada en su "Cartas al Señor D. Juan Valera. VI.", Revista Ecuatoriana, entrega III, t. II, n. ${ }^{\circ} 15$ (marzo de 1890): 87-98; y en “Carta 
Como católico a ultranza ("en religión soy católico y en política conservador"), ${ }^{15}$ Mera comenzará su ya citado ensayo afirmando que todo lo creado es obra de la omnipotencia de Dios y gobernado por "leyes superiores que reglan y gobiernan las infinitas partes del universo: leyes ocultas y misteriosas, y que están por lo mismo léjos de la comprensión y del poder del hombre", ${ }^{16}$ y en las que está incluido el propio devenir del ser humano y su(s) historia(s).

Igualmente, y partiendo de los postulados herderianos sobre la organicidad relacional entre el ser humano y las leyes de la naturaleza/universo (concepto romántico de "analogía"), Mera afirmará las irreductibles especificidades de los pueblos basada tanto en el determinismo de sus localismos geográficos ("En la variedad de la naturaleza está la variedad del hombre", ${ }^{17}$ de ahí su diversidad racial y cultural) como en las influencias que, secundariamente, aquellos ejercen mediante sus plurales usos y costumbres, tradiciones, creencias, etc. Y también, como en el caso del universo, ello responde a "cierta fuerza oculta que hay en la misma creación y que le gobierna de una manera absoluta é irresistible [...] y le obliga á ocupar un punto determinado y fijo en el mundo". ${ }^{18}$ Así, la historia propia de cada pueblo es entendida

al Señor Don Antonio Rubió y Lluch en contestación á la suya sobre el americanismo en la poesía", Revista Ecuatoriana, entrega XII, t. IV, n. ${ }^{\circ}$ XLVIII (diciembre de 1892): 465-475.

15. "Y no porque soy católico y conservador [...] dejo de ser fervoroso republicano, amante y defensor de toda libertad pública bien entendida, y respetuoso para con todo derecho legítimo; ni dejo de servir á mi patria en cuanto puedo", en "Cartas al Señor D. Juan Valera. VI", Revista Ecuatoriana..., 87-98. Mera, además de ser un vehemente propagandista católico (véase, por ejemplo, La Iglesia católica. Boceto de un poema [Quito: Imprenta de Juan Campuzano, 1874], http:/ / repositorio.casadelacultura.gob.ec/bitstream/34000/17910/2/ FBNCCE-msc07-Mera-6770.pdf), ocupó a lo largo de su vida numerosos cargos públicos, la mayoría de ellos ligados a la política, dada su temprana adscripción al conservadurismo, pues inmediatamente después del asesinato del presidente García Moreno (1875), en la reunión celebrada en el domicilio del obispo Ignacio Ordóñez Lazo en Quito con los más allegados colaboradores del finado presidente, incluido el propio Mera, se fundó el partido Sociedad Católica Republicana, futuro Partido Conservador Ecuatoriano, redactando aquel los correspondientes estatutos. Véase el "Programa Republicano" -1883- y sus "Bases" -1885-, en Enrique Ayala Mora, Lucha política y origen de los partidos en Ecuador, 4. a ed. (Quito: Corporación Editora Nacional, 1988), 339-342 y 343-344. Y en los mismos términos resulta su constante apelación a las creencias y valores cristiano-católicos en sus escritos, o la entusiasmada admiración por el presidente Gabriel García Moreno -al que inicialmente había criticado-en su obra ensayístico-literaria; por ejemplo, véase el poemario El héroe mártir. Canto a la memoria de García Moreno (Quito: Fundición de Tipos de Manuel Rivadeneira, 1876), http: / / repositorio.flacsoandes.edu.ec/ bitstream/10469 / 8486/2 / FBNCCE-msc12-Mera-9545.pdf o, su García Moreno, libro inédito de Juan León Mera (Quito: Imprenta del Clero, 1904).

16. “¿Es posible...?”. En Ojeada histórico-crítica ..., 465.

17. Ibíd., 466.

18. Ibíd., 465. 
como "una parte del inmenso conjunto de sucesos que constituyen la vida de la humanidad"; al tiempo, cada una de ellas, "dentro de sus límites, tiene su unidad, sus leyes y armonías" y forman parte de un "gran todo". ${ }^{19}$ Es decir, una genealogía intrínseca recorre todos los acontecimientos de la historia y de la vida de los seres humanos, enlazándolos y relacionándolos "con admirable armonía y lógica infalible". ${ }^{20}$ No hay azar ni sinsentido, todo se desarrolla e interrelaciona desde una necesidad ineludible, omniabarcante, total. En definitiva, es Dios desde su inefabilidad y omnipotencia quien "mueve los hilos" de todo cuanto existe, tanto en el pasado como en el presente o el futuro.

Para Mera, serán principalmente las costumbres -además de las religiones- el factor más importante en la fundamentación de la identidad de los pueblos, ya que aquellas se constituyen en su moral, y lo que es más importante para un romántico, en su espíritu: "Las costumbres son los rasgos típicos de los pueblos y forman su aspecto material y moral: son una especie de espíritu, si se me permite la espresión, que pone en movimiento todos los resortes del organismo individual y social". Además, y contemporáneamente en el caso americano, encontramos que "la organización moral primitiva de los americanos, su elemento espiritual, está patente en nuestra raza meztiza en todas partes", ${ }^{21}$ estableciéndose así una suerte de continuidad histórica -tan cara a los postulados historicistas románticos- entre el pasado y el presente de los pueblos del continente.

Por ello y si en toda literatura "aparece entera el alma de la sociedad", ${ }^{22}$ es absolutamente preciso fundar una literatura auténticamente americana -y ecuatoriana por extensión- que prescinda de las influencias foráneas (europeas principalmente) y que, sin descuidar en absoluto los aspectos formales y creativos, sea verdaderamente "original”: “¿Por qué no tenemos una literatura original?, ¿por qué no damos á lo ménos á nuestras producciones

19. Para las tres citas, véase el "Proemio" de su obra La dictadura y la restauración en la República del Ecuador, ensayo introductorio de Rafael Quintero López (Quito: Corporación Editora Nacional, 1982), 52.

20. Ibíd., 51.

21. “¿Es posible...?”. En Ojeada histórico-crítica..., 473. Anteriormente y en el mismo ensayo, Mera entiende que: "Por mas que los cambios políticos y religiosos y el poder irresistible de la civilizacion influyan en las costumbres de los pueblos, cerrando unas eras y abriendo otras distintas á las escenas de la vida, queda siempre la tintura primitiva, el color original que á calado en ellos y llegado á constituir parte de su naturaleza", 465 .

22. Ibíd., 471. Precisamente por la ya explicitada imitación de lo greco-latino en la literatura del continente, Mera había criticado anteriormente su nefasta influencia: "Si es verdad que la literatura de un pueblo es la espresion de su carácter y estado moral, nuestra literatura tiende á ser falsa y mentirosa, porque está pintando lo que ni se ve ni se siente en América", en "Vicios principales...". En Ojeada histórico-crítica..., 434. 
poéticas un colorido local y aspecto americano?, ¿por qué vaciamos nuestros pensamientos en moldes europeos?". ${ }^{23}$

Este reclamo de Mera a la originalidad en la literatura propia mediante su apelación a lo "americano" viene referido a todo aquello que diferencia a este continente de sus epígonos europeos, a saber, su especial naturaleza (climatología, fauna y flora, orografía), las distintas historias y costumbres de sus variados pueblos, etc., de modo que esta reivindicación "debe estar [basada] en los afectos, en las ideas, en las imágenes, en la parte espiritual de las pinturas, y todo en América abre el campo á esta originalidad". ${ }^{24} \mathrm{Y}$ es que la originalidad es para Mera el fundamento insoslayable de las obras bellas en literatura, el tiempo que la cualidad para su reconocimiento. No obstante, y en aras de una pedagogía artística en el necesario ejercicio de aprendizaje, recomienda nuestro autor la imitación -que no plagio- de los grandes autores literarios en los inicios de los jóvenes escritores, como ejercicio inexcusable para adquirir el necesario "buen gusto" artístico. Sin embargo, se lamentará Mera, "desde Samaniego y Salas, y talvez desde antes, puede asegurarse que todos [los artistas ecuatorianos] se han contentado con ser copistas, circunstancia que se nota áun en nuestros días y que impide el progreso del Arte, pues no le hay verdadero cuando la inteligencia se limita á seguir las huellas de otros, sin empeñarse en demostrar que posee la virtud creadora propia del genio". ${ }^{25}$

En consecuencia, no es la forma (la lengua) lo que se discute, pues esta debe siempre adecuarse -expresión- a su contenido, sino que es el propio concepto subyacente el que debe referirse a temas o historias y, sobre todo, valores genuinamente americanos, como ya señalaba al inicio de este apartado. ${ }^{26} \mathrm{Y}$ prueba de ese cambio deseado en aras de la "idea de dar un carácter

23. “¿Es posible...?”. En ibíd., 473-474.

24. Ibíd., 475.

25. "Conceptos sobre las artes", Revista Ecuatoriana, entrega IV, t. VI, n. ${ }^{\circ}$ LXIV (abril 1894): 121-148; 134.

26. Diez años antes de la publicación de la Ojeada, el también poeta Julio Zaldumbide, amigo y mentor de Mera, le reprocha a este en varias cartas que, a su juicio, resulta erróneo el concepto de "poesía nacional" profesado por Mera y consistente en componer poesías de temática indiana o referidas a la geografía del país y / o a "hechos nacionales" de la historia del Ecuador, pues en realidad, este tipo de composiciones deben denominarse como "poesía descriptiva". Véase "Cartas del Señor Don Julio Zaldumbide al Sr. D. Juan León Mera". En Memorias de la Academia Ecuatoriana Correspondiente de la Española (Quito: Tipografía y Encuadernación de la "Prensa Católica", 1934), 146-242. En este punto, mi mayor gratitud al Miembro de Número de la Academia Ecuatoriana de la Lengua Correspondiente de la Real Española (AEL) y poeta, señor don Bruno Marx Sáenz Andrade, por informarme de la existencia de dicha correspondencia y facilitarme su ubicación en la propia Academia Ecuatoriana de la Lengua para su fotocopiado. También hago extensivo mi agradecimiento a la Dra. Susana Cordero de Espinosa, directora de la Academia Ecuatoriana de la Lengua, por su amabilidad al ponerme en contacto con el Sr. D. Bruno Marx Sáenz Andrade. 
original y propio a la literatura americana, de abrirle un camino nuevo sin dejar de ser natural", ${ }^{27}$ son las nuevas literaturas emergentes en países como el propio Ecuador -no obstante, faltante aún de un mayor "afinamiento"-, Brasil o Cuba, y siempre utilizando el idioma español.

Por ejemplo, también resulta patente esa filiación romántica, cuando al inicio de su Ojeada (Capítulo I. "Indagaciones sobre la poesía quichua")28 define al género por excelencia más representativo y elevado para dicha estética cual es la poesía, en los siguientes términos:

Dios ha presentado patentes en sus obras la verdad, la armonía y la belleza, como caracteres que deben hacer conocer su mano poderosa y adorable á quien las contemple. Esos caracteres incluyen en sí aquella cosa inefable que percibe el alma racional con tanto deleite y encanto, y que los poetas inspirados por el cielo reducen al metro y la rima para hacerla sensible hasta por el órgano del oido. La poesía es, pues, la gracia innata de la naturaleza: es espiritual por el pensamiento y los afectos, y por la armonía moral que mueve la sensibilidad interior del hombre aun sin el ausilio de la armonía de los sonidos métricos que es obra del arte humana. ${ }^{29}$

Al igual que para Mera, la verdad, la armonía y la belleza son universales, esa "cosa inefable", esa "gracia innata de la naturaleza" que es la poesía, también se reviste del mismo carácter de universalidad, ya que posee un claro valor paidético -además de estético- para el ser humano de cualquier cultura: "La poesía es universal; para su desenvolvimiento en la naturaleza, para que el alma la comprenda, nada importan la situacion geográfica, la variedad de clímas ni el diverso genio y condicion de las razas humanas; en

27. “¿Es posible...?”. En Ojeada histórico-crítica..., 480. “No hai semilla mas fecunda que la del pensamiento cuando ha brotado de la naturaleza y de la verdad: el pensamiento de establecer una literatura original en América está sembrado en nuestra sociedad y tendrémos esa literatura". Ibíd., 480.

28. Valoro que es patente la intencionalidad de Mera al ubicar dicho estudio al comienzo de su Ojeada histórico-crítica, pues supone una clara reivindicación, no solo de una cultura y su lenguaje secularmente marginados a pesar de su producción literaria, sino, además, de una voluntad de integración al proyecto nacional de la etnia indígena. Prueba de ello es su comentario a la muerte de Atahualpa en dicho capítulo, y que obra como "símbolo integrador" a/ de una nación que es diversa, plural en su composición humana y cultural. Véase el libro de Regina Harrison, Entre el tronar épico y el llanto elegíaco: simbología indígena en la poesía ecuatoriana de los siglos XIX-XX (Quito: Abya-Yala / Universidad Andina Simón Bolívar, Sede Ecuador, 1996), 157-194.

29. “Indagaciones sobre la poesía quichua". En Ojeada histórico-crítica..., 1. "Para mí la naturaleza material no tiene poesía, sino por el soplo divino que la anima, por aquel no sé qué impalpable, invisible, misterioso que habla más á mi espíritu que á mis sentidos", en "Cartas al Señor D. Juan Valera. VI": 88. 
todas partes y en todas ocasiones ejerce su influencia con una misma fuerza y un mismo poder". ${ }^{30}$

En un sentido más amplio, el autor considera a la literatura como la más excelsa de las artes, puesto que "es la más noble, elevada y trascendental" de todas ellas, además de ser "cosmopolita e inmortal; le pertenecen el pasado, el presente y el porvenir [...] donde hay verdad, belleza y utilidad, allí está ella para tomarlas, levantarlas y enseñarlas a los hombres y a las generaciones".$^{31} \mathrm{Y}$ nuevamente los determinismos geográficos y climáticos (Herder) son para Mera, origen y causa de las diferentes literaturas nacionales, al tiempo que estas suponen un fiel reflejo de las respectivas costumbres y la propia moral de sus pueblos. "Cada pueblo tiene su literatura en que están retratados su ser moral, sus creencias, aspiraciones, costumbres é historia, así como la naturaleza material que lo rodea y nutre [...] todos han cultivado y cultivan las Bellas letras, cada uno conforme á la índole de su lengua, á su manera de pensar y sentir, á la naturaleza de su país, á sus costumbres y á sus tradiciones". 32

Y otro de los determinismos herderianos que Mera como romántico exclusivamente historicista hará suyo es el referido al denominado por él "ingenio artístico", 33 a saber, el condicionamiento que sobre este se ejerce en función de la diversidad geográfica-climática: "El ingenio artístico no es igual en todos los grupos en que está dividida la familia humana, siquiera no vivan ya entre las nieblas del salvajismo. La historia y la experiencia nos dicen cuál es el influjo que las condiciones de la tierra, el clima de cada latitud y las diferencias de razas ejercen en este ingenio". ${ }^{34}$

Así y según esta creencia, los climas templados favorecerían mucho más el desarrollo e, incluso, el tipo y calidad de las artes, mientras que aquellas

\section{Ibíd., 3.}

31. "Literatura y literatos. Carta á mi hijo J. Trajano", Revista Ecuatoriana, t. I, n. 5 (mayo de 1889): 169-174; para la cita en el texto, véase 170.

32. Ibíd., 172-173.

33. "Al fin, desde Samaniego y Salas, y talvez desde antes, puede asegurarse que todos [los artistas] se han contentado con ser copistas, circunstancia que se nota áun en nuestros días y que impide el progreso del Arte, pues no le hay verdadero cuando la inteligencia se limita á seguir las huellas de otros, sin empeñarse en demostrar que posee la virtud creadora propia del genio". En "Conceptos sobre las artes", Revista Ecuatoriana: 134. Para el tema de la creación poética (inspiración versus racionalización o, lo que es lo mismo, romanticismo versus neoclasicismo) y otras cuestiones relacionadas con la misma, véase Manuel Corrales Pascual, "Juan León Mera, crítica e historia literaria”. En Juan León Mera, una visión actual, ed. por Julio Pazos Barrera, 15-30 (Quito: Pontificia Universidad Católica del Ecuador / Universidad Andina Simón Bolívar, Sede Ecuador / Corporación Editora Nacional, 1994).

34. Ibíd., 123. 
regiones con ambientes fríos, generarían un arte más "melancólico y grave". Por ejemplo, y en el caso ecuatoriano, "el clima, el cielo tropical, los variadísimos aspectos de la corteza terráquea y otras circunstancias son propicias en el Ecuador a la concepción artística", ${ }^{35}$ no obstante, la absoluta penuria de modelos didácticos europeos para la enseñanza de las artes, producto -en parte importante- del propio aislamiento y, en general, por la "falta de estímulos" (ausencia de estudios literarios), retardan muy considerablemente el desarrollo artístico en el país, como ya se ha señalado al inicio de este trabajo.

También, otro factor que coadyuva a esa falta de desarrollo de la literatura nacional son las feroces, intransigentes y sectarias guerras entre los partidos políticos que determinan, en muchos casos según la adscripción o ideas políticas del literato en relación al gobierno de turno, la publicación -o no- de su obra:

Si no conociéramos á fondo el carácter de las pasiones de bandería, ése carácter irritable, intolerante; exclusivista, feroz y protervo, levantariamos nuestra voz, aunque débil y desautorizada, para decir á todos los partidos á todos los hombres: Alentemos el talento sea quien fuere la persona á quien se le ha dado Dios, protejámosle y levantémosle; ese es un tesoro que pertenece á la patria no á nosotros [...] ¿Qué nos importa que un ingenio pertenezca á tal ó cual comunión política? ${ }^{36}$

Aquí Mera se muestra extraordinariamente lúcido en su criterio, pues antepone la creación artística, y la contribución que esta supone para el país, a los mezquinos intereses políticos, a pesar de su propia adscripción al Partido Conservador. Es decir, se muestra consecuente con su proyecto integrador de "nación plural".

En este punto conviene destacar que tanto el cierto conservadurismo del escritor como sus profundas creencias católicas ("la Religión: es preciso estudiarla para conocerla, es preciso conocerla para amarla y practicarla, y es preciso amarla y practicarla para que ella nos abra los tesoros de sus beneficios. Estudiémosla con empeño entusiasta, y á la luz de la razón y de la fe iremos por ilación lógica al conocimiento de Dios, á su amor, á la necesidad de un culto, al Cristianismo, al Catolicismo, esto es á la posesión de la verdad"), ${ }^{37}$ implicaban un absoluto rechazo a determinados y fundamentales postulados del Romanticismo estético y político, tales como la primacía de la subjetividad del artista, su absoluta libertad de creación o la autonomía

35. Ibíd., 125.

36. "Defectos y mal estado...". En Ojeada histórico-crítica..., 460-461.

37. “Discurso del Señor D. Juan León Mera, Presidente del Ateneo", s. f., s. r, 9, http:/ / repositorio.flacsoandes.edu.ec/ bitstream / 10469 / 8119/2 / FBNCCE-Mera-5373-PUBCOM.pdf. 
moral del mismo, la oposición a las academias y sus reglas, el radical ejercicio de la democracia popular (sin tutelas, condicionantes o paternalismos), la solidaridad -que no caridad-con las clases subalternas, el derecho a la rebelión de estas, ${ }^{38}$ etc. Por ejemplo y entre otros, Mera hace una apasionada denuncia y repulsa de la introducción de cuestiones referidas a lo político en poesía, o de términos descorteses, chabacanos, insultantes o soeces en la misma, o que, así mismo, atenten contra las buenas costumbres:

Lo que sí he cuidado de no conservar es el gran número de versos ofensivos de la moral, y no pocos con que se ha tratado de lastimar el buen nombre de algunas personas [...] [Nuestro pueblo] déjase arrebatar por los impulsos del momento, y por cada elogio á los personajes de sus simpatías, echa á los que no lo son venenosas saetas en forma, de serventesios. ó seguidillas, rudos con frecuencia, pero siempre fáciles y rebosantes de dañina intención. Entre las coplas de esta compilación creo, pues, no haber incluido ninguna de color escandaloso. ${ }^{39}$

No obstante lo antedicho y como ya se ha destacado, sí compartía las creencias más marcadamente historicistas del movimiento romántico, pues, y entre otras razones, entiendo que amparaban y justificaban al (su) propio proyecto nacional integrador y, con él, a su deseada autóctona y "americana" cultura. Y prueba de esa voluntad integradora será su reivindicación de los "cantares populares" como parte de la propia cultura literaria ecuatoriana, al tiempo que como manifestación de su conciencia republicana:

El retrato moral del pueblo está en sus coplas [...]. Es necesario no menospreciar la musa popular, y se debe recoger y conservar sus frutos, escogiéndolos, por supuesto, porque de seguro son útiles por muchos conceptos; y en todo caso se honra al pueblo, que no á causa de su falta de ilustración y de sus maneras incultas deja de formar parte dé la familia humana. Especialmente en el sistema republicano el pensamiento y el corazón del pueblo, sus derechos y deberes, sus costumbres y aspiraciones, son partes muy principales en la urdimbre de la vida civil y política; ¿por qué sus afectos y recuerdos, sus dolores y esperanzas

38. "Por justa que sea una revolución, mientras ella domina no se progresa, y luégo deja consecuencias nada buenas que duran largo tiempo", "Cartas al Señor D. Juan Valera V", Revista Ecuatoriana, entrega III, t. II, n. 15 (marzo 1890): 15-78. En esta "Carta", Mera aporta una valiosa y pormenorizada información estadística sobre la escolarización en el Ecuador desde su fundación como República hasta su propia época con interesantes reflexiones al respecto.

39. "Estudio [Introducción] sobre los Cantares del Pueblo Ecuatoriano". En Antología Ecuatoriana. Cantares del Pueblo Ecuatoriano, comp. por Juan León Mera, edición hecha por orden y bajo el auspicio de la Academia Ecuatoriana, Quito, 1892, X, http:/ / bdh-rd.bne.es/viewer. vm?id=0000044217\&page $=1$. Sobre esta cuestión de la depuración de términos no deseados por Mera y en relación a la citada publicación, véase María de Lubensky, "Política lingüística de Juan León Mera y los Cantares del Pueblo Ecuatoriano". En Juan León Mera, una visión actual..., 55-67. 
expresados sencillamente en serventesios y seguidillas, no han de entrar en la vida literaria? ${ }^{40}$

También debe tenerse en cuenta para mejor valorar en Mera esa necesidad "fundadora" de una nueva literatura americana, su profundo desencanto -que no con los adelantos técnico científicos de la época- por el, a su juicio, paralelo deterioro moral que, en forma de vacuidad vital y hastío existencial, iba adquiriendo el progreso en las naciones más avanzadas, particularmente las europeas, y que amenazaba con su incipiente propagación en América el futuro (moral) del continente. Efectivamente, el asentamiento en aquellas naciones de la ideología materialista tales como el nihilismo, racionalismo a ultranza, paganismo o el lujo y las modas foráneas, el realismo en literatura, así como "las inmorales y disolventes doctrinas del socialismo y comunismo tratando de suplantar á la santa sabiduría del Evangelio para corromper el corazon de la sociedad; las sombras de Proudom, de San Simon, de Fourrier inspirando á sus atolondrados discípulos las ideas del mal que deben entronizar en la tierra", ${ }^{41}$ implicaban, en suma, el progresivo "olvido de todo lo espiritual y eterno", ${ }^{42}$ al tiempo que un pernicioso escepticismo. E igualmente, esta incredulidad suponía un lastre, cuando no imposibilidad para poder plantearse metas de futuro a nivel societario o nacional y que respondieran a los verdaderos anhelos humanos de felicidad y desarrollo armoniosos en lo material y espiritual.

Y es que, por el contrario, América todavía tenía un largo y esperanzado camino por recorrer en todos los ámbitos de la cultura y de la civilización, plena de juventud y vitalidad, lozana y robusta, "animada por tantos principios de felicidad [...] no puede tener astio de nada, no lo tiene [...] ni buscar en el árido materialismo el orígen y fin de su existencia, la meta de todas sus aspiraciones" ${ }^{43}$ Es decir, el continente está en un momento privilegiado de su existencia histórica y debe, por tanto, buscar su camino de desarrollo y valores propios, rechazando de plano los "falsos ídolos" europeos; en ello se juega su futuro y, por ello mismo, la (nueva) literatura americana está llamada a servir de guía "espiritual" -educativo/moral- a las naciones que integran a aquel.

40. "Estudio sobre los cantares del pueblo ecuatoriano". En Antología ecuatoriana. Cantares del pueblo ecuatoriano (Quito: Imprenta de la Universidad Central del Ecuador, 1892), XXIII, http: / / bdh-rd.bne.es / viewer.vm?id=0000044217\&page=1.

41. "Vicios principales...". En Ojeada histórico-crítica..., 448-449.

42. "Cartas al Señor D. Juan Valera. III", Revista Ecuatoriana, entrega II, t. II, n. ${ }^{\circ} 14$ (febrero de 1890): 41. También afirmará en dicha "Carta" que "el único medio para que los pueblos lleguen á una civilización perfecta en lo posible, es el Cristianismo": 41.

43. “Vicios principales...". En Ojeada histórico-crítica..., 434. 


\section{SOBRE EL "BUEN GUSTO" O LA POÉTICA NEOCLÁsica en JuAN LeÓN Mera}

Si hay un poeta al que Mera valora con verdadera y fundamentada admiración en su Ojeada, este es José Joaquín Olmedo, pues "en cada página, en cada estrofa manifiesta Olmedo la espontaneidad, el atrevimiento sublime y la celestial brillantez de su genio incapaz de someterse al rigor de los preceptos artísticos que podía haber detenido su vuelo"; ${ }^{44}$ y particular mención le merece el poema "Canto a Bolívar" -también nominado como "La victoria de Junín"-, pues, y entre otras cuestiones, supone en su época uno de los mayores textos "heroicos" de la emancipación del Ecuador de su potencia colonial y, por tanto, del relato fundador de la "invención de la nación" . ${ }^{45} \mathrm{Al}$ tiempo, dicho poema como por extensión de toda la obra de Olmedo, recibe uno de los mayores elogios que Mera pueda dedicar a cualquier autor, a saber, su "buen gusto".

A este tenor, resulta necesario explicitar que, para Mera, la estética entendida como "el auténtico conocimiento de lo bello" es considerada como universal -aplicable en todo tiempo y lugar- y a priori -metafísica-, puesto que no la ha inventado el ser humano, sino que "existe esencialmente en la creación [...], viva, más latente en la naturaleza, ha sido declarada y propuesta a las Artes por el estudio y la reflexión, para que se sujetasen a sus leyes en la creación de sus obras". Y es precisamente gracias a esas leyes (universales) que solo la razón deduce por lo que la estética es entendida, en la época del autor, como el verdadero y exacto fundamento de la crítica artística, pues se ha convertido en "una autoridad que obra sujetándose a leyes justas y sabias", ${ }^{46}$ a pesar de su lamentable ausencia en Ecuador. Es decir, es la normativa que permite objetivar universalmente, tanto al "buen gusto" como a su corolario finalístico, esto es, a la belleza.

Un ejemplo interesante al tiempo que didáctico sobre esa (necesaria) aplicación del "buen gusto" es su anuencia en introducir algunos términos indígenas (quichuas) en la nueva literatura, siempre y cuando se refieran a cuestiones en las que una traducción directa al español pueda alterar su

44. “Don José Joaquín Olmedo”. Ibíd., 253.

45. Vease Benedict Anderson, Comunidades imaginadas. Reflexiones sobre el origen y la difusión del nacionalismo (México: Fondo de Cultura Económica, 1993).

46. "Conceptos sobre las artes", Revista Ecuatoriana...: 124. Para ambas citas en el párrafo del texto. En un sentido más ampliamente cultural y no solo referido a lo artístico, Mera opina que "La crítica es arte tan necesaria, que donde no se la practica falta uno de los elementos principales del progreso de las ciencias, las letras y demás conocimientos humanos". En “Carta de Juan León Mera al Señor Don Antonio Rubió y Lluch...” , 465-475. 
verdadero sentido. Así pondrá como ejemplo el término "Pachacámac", que solo adquiere su pleno significado en el contexto de la cosmovisión indígena, desvirtuándose en su traducción como Dios en la acepción occidental y cristiana. Sin embargo, dicha novedosa utilización debe responder a lo útil y razonable, y estar siempre basada en el citado "buen gusto", pues es este quien "representa la verdad en las obras de la inteligencia". ${ }^{47}$

Efectivamente, el "buen gusto" como categoría fundamental en la poética neoclásica, será articular en la conceptualización literario-poética de Mera, pues su rol formal y constructivo determinará, a su juicio, toda creación literaria. Repetida en numerosas ocasiones a lo largo de la Ojeada y en otros escritos de carácter ensayístico, aquella se reviste e implica diversas cuestiones como la necesaria imitación de la naturaleza (universalidad), la obligada adecuación entre la forma y el contenido, la sencillez y simplicidad formalexpresiva (por ejemplo, Mera criticará vehementemente la poesía culterana de Góngora), el requerido didactismo del tema, etc. ${ }^{48} \mathrm{Y}$ cuestión que no solo atañe a la literatura, sino que también, y poniendo como ejemplo a la arquitectura, resulta extensiva para toda disciplina artística: "consúltese que no es difícil ni costoso, la regularidad de la planta, las proporciones convenientes de las partes del edificio, la simetría de puertas y ventanas; procédece de igual manera en lo interior [...] En Quito hay abundancia de casas que no dejan qué desear en punto á simetría y otras condiciones requeridas por el Arte". ${ }^{49}$

Es decir, Mera entiende que para cualquier género artístico, y en su quehacer creativo, debe aplicarse una poética basada en el orden, la medida y la proporción, sencillez y claridad, constituida y construida mediante la razón, fundamento a su vez del imprescindible "buen gusto" reclamado para el arte. $\mathrm{Y}$ aunque ello, evidentemente, contraste con su ya mentada adscripción a ciertos postulados del Romanticismo, no supone para el autor una disparidad antagónica, sino más bien un necesario por insustituible complemento en la búsqueda de la progresiva y ansiada perfección (ideal) en el arte, finalidad esta universalmente compartida por los artistas de su época: "La perfección del arte para que llene un fin social ó un fin puramente recreativo, debe ser el constante anhelo de todos cuanto le cultivan". ${ }^{50}$

47. “¿Es posible...?”. En Ojeada histórico-crítica..., 485.

48. En parecidos términos y con la finalidad de regenerar a la vacua poesía ecuatoriana del momento, se pronunciará el conocido poeta, escritor y diplomático Remigio Crespo Toral en su corto ensayo de juventud titulado "Un nuevo ideal poético" [1883]. En Teoría del arte en el Ecuador, estudio introductorio de Edmundo Ribadeneira, 451-458. (Quito: Banco Central del Ecuador / Corporación Editora Nacional, 1987).

49. "Conceptos sobre las artes", Revista Ecuatoriana: 129.

50. “Carta al Señor Don Antonio Rubió y Lluch...", Revista Ecuatoriana: 470. 
Para Mera el Arte, ${ }^{51}$ además de estar sujeto a su necesario progreso en pos del ideal de belleza y perfección ya señalados - guiados por la crítica artística y el "buen gusto"- es, al tiempo, un factor muy importante -si no determinante- en el proceso emancipatorio de las naciones desde su original estadio primitivo al civilizado (idea de progreso). Es por ello que, infiere, a mayor desarrollo y perfectibilidad de las artes, mayores grados de progreso y civilización de las naciones y sus pueblos: "El cultivo de las Artes contribuye á la civilización de los pueblos -verdad repetida por muchos escritores- y el desarrollo y perfección que ellas alcanzan sirven para medir el grado de cultura de las naciones -otra verdad harto conocida-", para afirmar unas pocas líneas a continuación y en el mismo párrafo que "El pueblo que comienza á dejar sus condiciones primitivas empieza á sentir afición á las Artes, y mientras más disposiciones muestra para cultivarlas, mayor es la probabilidad de que avanzará pronto en la civilización. Percibe como á lo lejos la armonía, entrevé los seductores rasgos de la belleza, se entusiasma y corre tras ellos". ${ }^{52}$

A tenor de lo citado, se colige la necesidad en el amparo que debe darse a las Bellas Artes, pues conforman parte importante del propio honor de las naciones: "aunque la protección no es todavía lo que debiera ser ahora se comprende la importancia de las Bellas Artes y se quiere de veras su adelanto como provecho y como honra nacionales" ${ }^{\prime 5} \mathrm{E}$ importancia de las mismas por obrar como una suerte de escala comparativa del propio progreso de las naciones: "En la Literatura y las Bellas Artes, como ya se ha dicho muchas veces, se refleja principalmente la cultura de los pueblos. Nación en que ellas no tienen altares y adoradores, no es nación civilizada [...] ¡Y la Pintura!, iy la Estatuaria!, iy la Arquitectura! Tres reinas con almas de genio, ante las cuales se descubren reverentes los pueblos civilizados". ${ }^{54}$

En relación a estas tres últimas citas, valoro conveniente destacar que ese "desarrollo y perfección", ese "adelanto" que Mera espera en la diacronía evolutiva de las artes como sinónimo de civilización, son entendidos como lugar de la enunciación desde los parámetros que el "buen gusto" y la crítica artística sancionan, es decir, son los modelos estético-artísticos eurocéntricos -en parte todavía vigentes en aquel continente-, más la reclamada originalidad que el "americanismo" aporta, el "lugar" desde el que se juzga la

51. El hecho de escribir con mayúscula el término "Arte" por parte de Mera (así lo transcribo), ya denota su concepción universalista y metafísica con respecto a este, cuestión además y en su época totalmente eurocéntrica de acuerdo a los concepciones estéticas vigentes.

52. "Conceptos sobre las artes", Revista Ecuatoriana: 123, para ambas citas en el párrafo del texto.

53. Ibíd., 143.

54. “Discurso del Señor D. Juan León Mera...", 11-12 y 14. 
corrección -o no- de las obras artísticas y, por tanto, del grado alcanzado en la evolución civilizatoria de los pueblos que las crean.

$\mathrm{Y}$ es que para Mera, un factor determinante tanto para la educación en ese "buen gusto" como, al tiempo, en su progresivo afianzamiento y desarrollo entre la ciudadanía, es la pedagogía que al efecto suponen las exposiciones artísticas, ya que estas "son también medios poderosos de adelantamiento y caminos que conducen al pueblo hacia el buen gusto. Dos hemos tenido en la Capital, en 1852 y 1892. ¡Cuarenta años de intervalo! En la vía del progreso son una eternidad". 55

Evidentemente, para Mera las artes constituyen un componente indispensable, no solo para el necesario desarrollo de los más fundamentales ámbitos de la cultura como la ciencia o la técnica hacia la modernidad, sino que también implican una suerte de educación cívica para los pueblos mediante el "buen gusto" que sus obras representan y difunden, es decir, y bastante común en los escritores de la época, ${ }^{56}$ vehiculan ejemplos "moralizantes" que sirvan para constituirse y reconocerse como nación unitaria que profesa unos valores comunes, al tiempo que un universo simbólico compartido: "Al son de la lira se deben cantar las alabanzas de los héroes, recordando las

55. “Conceptos sobre las artes...", 145. Por ejemplo, véase en relación a las exposiciones internacionales como vehículo generador de identidad nacional, basada en la etnicidad, Blanca Muratorio, "Nación, identidad y etnicidad: imágenes de los indios ecuatorianos y sus imagineros a fines del siglo XIX". En Imágenes e imagineros. Representaciones de los indígenas ecuatorianos, siglos XIX y XX, ed. por Blanca Muratorio, 109-196 (Quito: FLACSO Ecuador, 1994).

56. Un ejemplo de lo antedicho es el escrito del importante e influyente diplomático, escritor, poeta y pintor contemporáneo de Mera, Honorato Vázquez, quien en su artículo "Sobre el carácter nacional de la poesía" escribe: "Nosotros queremos el estudio de la forma como revelación de la idea poética [...], queremos estudiar la belleza ideal compenetrada con la palabra humana; nosotros pedimos que la poesía disponga de los elementos que presta la tradición del buen gusto, que los amalgame discretamente sin discernir siglos ni escuelas y los ponga al servicio de todo lo grande, de todo lo bello, de todo lo bueno". A ello cabría añadir asimismo, la coincidencia con Mera en aquellos aspectos metafísicos, universalizantes, eurocéntricos y confesionales sobre la belleza, la creación artística y el propio arte, ya desarrollados en el texto: "La forma poética no es griega, ni romana, no es programa de escuela, es determinación bella de una idea bella; distribución de la forma interna, de la organización de la obra, arreo exterior de la misma, es hallazgo de los grandes ingenios cualesquiera que sean su patria y su siglo, es ejemplo que ha de imitarse, doctrina que ha de aprenderse para una práctica juiciosa, supuestas las dotes morales y estéticas del poeta" o, "La disciplina del espíritu en los eternos principios del bien y de la verdad, el estudio de la belleza en sus manifestaciones, son el resumen de una Poética universal". También y platónicamente sentenciará: "La belleza es una, no tiene tiempo ni patria: es una como la moral, la verdad", para afirmar que "Nuestra poesía para ser nacional debe ser eminentemente cristiana", Revista Ecuatoriana, t. II, n. ${ }^{\circ} 15$ (marzo 1890): 107, 102, 106, 108 y 112-113. 
hazañas con que han salvado la patria, y dádola libertad y gloria, y este será uno de los mas eficaces estímulos para que en adelante repitan las nobles acciones, y ciñan su frente con nuevos y eternos lauros". ${ }^{57}$

En definitiva, es la cosmovisión que la idea de progreso instituye en su diktat universalizante, ${ }^{58}$ ahora como "materialización" estético-artística -y simbólica- en la constitución de lo propio, de lo nacional, bien entendido que desde la exclusiva y excluyente concepción conservadora y católica que ciertas e influyentes élites ejercen, divulgan e instituyen para toda la población, ahora concebida como un homogéneo universal..$^{59}$

Así, Mera y a pesar de su pregonado distanciamiento de los modelos europeos, asume el carácter metafísico del arte y su ideal de belleza postulado por aquellos, ejerciendo su creencia religiosa de gozne que permite aunar en una suerte de sincretismo sistemas estéticos tan contrapuestos (romanticismo versus neoclasicismo), y teniendo siempre como una de las finalidades del mismo, esa reiteradamente reclamada educación cívico-moral como medio insoslayable en la consolidación de su proyecto integrador de nación. ${ }^{60}$

57. “Vicios principales...". En Ojeada histórico-crítica..., 428-429.

58. Es sabido que la idea de progreso preside y justifica al denominado proceso civilizatorio de toda nación moderna que se precie para poder "estar" en la historia, constituyéndose en un tópico en todo tipo de discursos de la época. En el Ecuador decimonónico y aun después, dicha idea será objeto de constante invocación en numerosos escritos, actos oficiales, etc.; en este sentido, y como un ejemplo entre otros muchos, en el discurso pronunciado por el poeta, escritor y diplomático Leonidas Pallares Arteta se lee lo siguiente: "Las artes buscan hoy en nuestro suelo sombra benéfica bajo las alas de la ciencia. El progreso, ley natural, política y social, invade como torrente acaudalado las más lejanas regiones de la tierra [...]. Prende en sus rudos pechos [de los pueblos más atrasados o salvajes] la chispa libre e inmortal de la razón iluminada por la sabiduría, que engendra acciones grandes y grandes pensamientos, y les llama á vivir en la Historia, enseñando á pronunciar su nombre difícil á las edades de lo porvenir". "Discurso leído por el Señor Don Leonidas Pallares Arteta la noche del 15 del presente en el concierto de "La Sociedad Filarmónica" (Quito: Imprenta del Gobierno, 1884), 7-8, http: / / repositorio.casadelacultura.gob.ec/bitstream/34000/18026/2 / LBNCCE-msc06-Palleres-6800.pdf.

59. "Pese a las polémicas entre bandos, la patria que soñaron siempre fue una sola: una república hispánica y católica, patriarcal y conservadora. Finalmente, este es el significado que transmiten las novelas ecuatorianas del siglo XIX, escritas entre 1855 y 1893. Al narrar la nación en clave estética, de modo histórico y en tono crítico, los primeros novelistas fundaron un país imaginado por las élites sociales, que habían heredado la cultura y el territorio de sus padres, los mismos que sostuvieron el régimen de castas y exclusión de la Colonia española durante siglos. La casa que edificaron los primeros ecuatorianos no podía ser muy distinta del palacio imperial, pues la tuvieron que construir con los mismos ladrillos de sus ruinas". César Eduardo Carrión Carrión, La novela ecuatoriana del siglo XIX..., 305.

60. Ejemplo paradigmático de ese "compromiso patriótico" en relación a la escritura será la publicación con fines divulgativos de su Catecismo de geografía de la República del 


\section{CONCLUSIONES}

La voluntad de establecer un (nuevo) canon literario en Ecuador por parte de Mera que incluyese no solo a la poesía "culta", formalmente construida a partir de los postulados neoclásicos, si no a los cantares populares o a la propia poesía en lengua quichua, obedece a su proyecto nacional integrador a partir de la constatación y aceptación de una realidad plural en lo social, cultural y étnico. También merece destacarse su reivindicación de la mujer en ese proyecto y en igualdad con el hombre, algo inusitado para la mentalidad de la época y más por parte de una persona declarada "conservadora y católica", al igual que en ese sentido, la edición de determinadas obras de aquellas. ${ }^{61}$

Y proyecto integrador que, si bien debía estar basado en la dogmática y moral católica (por ejemplo, Mera era partidario de la evangelización de los pueblos autóctonos de la Amazonía), ello no impedía profesar públicamente el necesario respeto por las costumbres y tradiciones de las culturas indígenas. Al tiempo, sus postulados romántico-historicistas le permitían fundamentar y establecer una hilazón histórica entre las culturas ancestrales y el propio presente que dotara de continuidad sincrónica y, por tanto de sentido, a ese proyecto nacional.

E interrelacionadamente con lo anterior, era el rol de primer orden que estaba llamada a representar la literatura como factor educativo -patriótico y moral-en esa construcción. Efectivamente, la escasa calidad de la mayoría de la producción en ese ámbito, según comenta críticamente Mera, más sus

Ecuador (Quito: Imprenta Nacional, 1875 [1873]), https: / / archive.org/ details/ catecismodegeog00meragoog; Catecismo de geografía de la República del Ecuador, Texto de enseñanza para las escuelas ecuatorianas, adoptado por el Supremo Gobierno, 2. ${ }^{\text {a }}$ ed. corregida y aumentada notablemente, y hecha con autorización del mismo Supremo Gobierno (Guayaquil: Imp. de La Nación, 1884), https: / / iiif.lib.harvard.edu/manifests/view/drs:4776723\$1i, y su ulterior Catecismo explicado de la Constitución de la República del Ecuador (Quito: Imprenta del Clero, 1894).

61. Véase el sorprendente -en su contexto histórico-cultural- capítulo titulado "Doña Dolores Veintemilla de Galindo. La educación de la mujer entre nosotros". En Ojeada histórico-crítica..., 270-286. También, la edición crítica de las Obras selectas de la célebre monja de Mejico, sor Juana Inés de la Cruz, precedidas de su biografía y juicio crítico sobre todas sus producciones (Quito: Imprenta Nacional, 1873), https://books.google.com.ec/bo oks? id=bMcGAQAAIAAJ\&printsec $=$ frontcover\&hl=es\&source=gbs_ViewAPI\&redir_ $\mathrm{esc}=\mathrm{y} \# \mathrm{v}=$ onepage \&q\&f$=$ false, especialmente el "Prólogo" referido también a la denuncia de la consideración de la mujer en su época. Y sobre esta última publicación, el trabajo de Yolanda Montalvo Bustos, “Mera y sor Juana Inés de la Cruz". En Juan León Mera..., 69-89 (Quito: Pontificia Universidad Católica del Ecuador / Universidad Andina Simón Bolívar, Sede Ecuador / Corporación Editora Nacional, 1994). 
propias ideas en lo que debía ser la labor creativa literaria, le impelen a establecer un "orden" poético para la misma. Por ello, entiendo que la canónica neoclásica representa a su juicio el mejor antídoto contra los excesos barrocos, el melifluo sentimentalismo cursi romántico o cualquier amaneramiento mimético. De ahí que la sencillez, claridad, concisión, naturalidad, razonamiento creativo, medida, proporción, etc., de la poética neoclásica le resulten -en el concepto y en la práctica creativa-ideales en esa ansiada regeneración literaria. Y ejemplo de ello será su demostración a través del ejercicio de la crítica literaria -ausente en el Ecuador de su tiempo- de la importancia y validez de esa necesaria canónica.

En definitiva, el gran conocimiento literario de Juan León Mera, además de su dedicación y exigencia, tanto en la creación poético-novelística como ensayística, unido a su proyección "patriótica", ${ }^{62}$ nos muestran al hombre comprometido con su momento histórico y político, a la par que con el arte como guía estética en el devenir de la incipiente y frágil nación. Su meditada a la par que ingente y plural obra así lo demuestra.

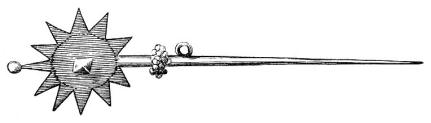

62. Por ejemplo, muy nombrada será su polémica en 1887 con el alcalde de Quito, el liberal moderado Francisco Andrade Marín y otras autoridades municipales, y particularmente con el a la sazón embajador español en Ecuador, Manuel Llorente Vázquez, a raíz de la "mutilación" por parte del cabildo de diversos elementos simbólico-emancipadores del coloniaje español en la escultura de Sucre, a resultas de las quejas de dicho embajador, y a las que cabría sumar igualmente la pretensión del diplomático de la supresión de determinadas estrofas "ofensivas a España" del Himno Nacional compuesto anteriormente por Mera en su letra (1865). 


\title{
FUENTES Y BIBLIOGRAFÍA
}

\author{
FUENTES PRIMARIAS
}

\section{Archivos}

Archivo Biblioteca Aurelio Espinosa Pólit (BEAEP).

Archivo de la Biblioteca del Ministerio de Cultura y Patrimonio (AHMCyP)

\section{FUENTES SECUNDARIAS}

Aguinaga Zumárraga, Susana. "La lírica romántica". En Historia de las literaturas del Ecuador. Literatura de la República. 1830-1895, coordinado por Diego Araujo Sánchez, 91-124. Quito: Universidad Andina Simón Bolívar, Sede Ecuador / Corporación Editora Nacional, 2002.

Anderson, Benedict. Comunidades imaginadas. Reflexiones sobre el origen y la difusión del nacionalismo. México: Fondo de Cultura Económica, 1993.

Araujo Sánchez, Diego. "El romanticismo en Ecuador e Hispanoamérica". En Historia de las literaturas del Ecuador. Literatura de la República. 1830-1895, coordinado por Diego Araujo Sánchez, 55-70. Quito: Universidad Andina Simón Bolívar, Sede Ecuador / Corporación Editora Nacional, 2002.

Ayala Mora, Enrique. Lucha política y origen de los partidos en Ecuador, $4^{\text {a }}$ ed. Quito: Corporación Editora Nacional, 1988.

“Cartas del Señor Don Julio Zaldumbide al Sr. D. Juan León Mera". En Memorias de la Academia Ecuatoriana Correspondiente de la Española. Quito: Tipografía y Encuadernación de la "Prensa Católica", 1934, 146-242.

Carrión, César Eduardo. "La novela ecuatoriana del siglo XIX como relato del surgimiento de la nación (1855-1893)". Tesis de doctorado. Universidad Andina Simón Bolívar, Sede Ecuador. 2016.

Crespo Toral, Remigio. "Un nuevo ideal poético" [1883]. En Teoría del Arte en el Ecuador, estudio introductorio de Edmundo Ribadeneira. Quito: Banco Central del Ecuador / Corporación Editora Nacional, 1987, 451-458.

Corrales Pascual, Manuel. "Juan León Mera, crítica e historia literaria". En Juan León Mera, una visión actual, editado por Julio Pazos Barrera, 15-30. Quito: Pontificia Universidad Católica del Ecuador / Universidad Andina Simón Bolívar, Sede Ecuador / Corporación Editora Nacional, 1994.

González Suárez, Federico. Hermosura de la naturaleza y sentimiento estético de ella, preámbulo de Marcelino Menéndez Pelayo. Madrid: Est. Tipográfico "Sucesores de Rivadeneyra" / Impresores de la Real Casa, 1908. http:/ / repositorio. casadelacultura.gob.ec/ bitstream/34000/983/1/ FR1-L-000335-GonzalezHermosura.pdf.

Harrison, Regina. Entre el tronar épico y el llanto elegíaco: simbología indígena en la poesía ecuatoriana de los siglos XIX-XX. Quito: Abya-Yala / Universidad Andina Simón Bolívar, Sede Ecuador, 1996. 
Lubensky, María de. “Política lingüística de Juan León Mera y los Cantares del Pueblo Ecuatoriano". En Juan León Mera, una visión actual, editado por Julio Pazos Barrera, 55-67. Quito: Pontificia Universidad Católica del Ecuador / Universidad Andina Simón Bolívar, Sede Ecuador / Corporación Editora Nacional, 1994.

Mera Martínez, Juan León. “Cartas al Señor D. Juan Valera. III". Revista Ecuatoriana, entrega II, T. II, n. ${ }^{\circ} 14$ (febrero 1890): 37-45.

. "Cartas al Señor D. Juan Valera. V". Revista Ecuatoriana, entrega III. T. II, n. ${ }^{\circ}$ 15 (marzo 1890): 78-86.

. "Cartas al Señor D. Juan Valera. VI.". Revista Ecuatoriana, entrega III. T. II, n. ${ }^{\circ}$ 15 (marzo 1890): 87-98.

- “Carta al Señor Don Antonio Rubió y Lluch, en contestación á la suya sobre el americanismo en la poesía". Revista Ecuatoriana, entrega XII. T. IV, n. ${ }^{\circ}$ XLVIII (diciembre 1892): 466-475.

- Catecismo de geografía de la República del Ecuador. Quito: Imprenta Nacional, 1875 [1873]. https: / / archive.org / details / catecismodegeog00meragoog.

- Catecismo de geografía de la República del Ecuador. Texto de enseñanza para las escuelas ecuatorianas, adoptado por el Supremo Gobierno. 2. ${ }^{\text {a }}$ ed. corregida y aumentada notablemente, y hecha con autorización del mismo Supremo Gobierno. Guayaquil: Imp. de La Nación, 1884. https: / / iiif.lib.harvard.edu/manifests / view / drs:4776723\$1i.

. Catecismo explicado de la Constitución de la República del Ecuador. Quito: Imprenta del Clero, 1894.

. "Conceptos sobre las artes". Revista Ecuatoriana, entrega IV. T. VI, n. ${ }^{\circ}$ LXIV (abril 1894): 121-148.

. Discurso del Señor D. Juan León Mera, Presidente del Ateneo. Quito: s. f.

. El héroe mártir. Canto a la memoria de García Moreno, 2. a ed., Quito: Fundición de Tipos de Manuel Rivadeneira, 1876. http:// repositorio.flacsoandes.edu. ec/bitstream/10469 / 8486/2 / FBNCCE-msc12-Mera-9545.pdf.

. García Moreno, libro inédito de Juan León Mera. Quito: Imprenta del Clero, 1904. - La dictadura y la restauración en la República del Ecuador. Estudio introductorio de Rafael Quintero López. Quito: Corporación Editora Nacional, 1982.

. La Iglesia Católica. Boceto de un poema. Quito: Imprenta de Juan Campuzano, 1874, http: / / repositorio.casadelacultura.gob.ec/bitstream/34000/17910/2 / FBNCCE-msc07-Mera-6770.pdf.

. "Literatura y literatos. Carta á mi hijo J. Trajano". Revista Ecuatoriana. T. I, n. ${ }^{\circ}$ 5 (mayo de 1889): 169-174.

- Obras selectas de la célebre monja de Méjico, sor Juana Inés de la Cruz, precedidas de su biografía y juicio crítico sobre todas sus producciones. Quito: Imprenta Nacional, 1873, https://books.google.com.ec/books?id=bMcGA QAAIAAJ\&printsec $=$ frontcover\&hl=es\&source $=$ gbs_View API\&redir_ $\mathrm{esc}=\mathrm{y} \# \mathrm{v}=$ onepage $\& \mathrm{q} \& \mathrm{f}=$ false.

. Ojeada histórico-crítica sobre la poesía ecuatoriana desde su época más remota hasta nuestros días. Barcelona: Imprenta y Litografía de José Cunill Sala, 1893.

- Ojeada histórico-crítica sobre la poesía ecuatoriana desde su época más remota hasta nuestros días. Quito: Imprenta de J. Pablo Sanz, 1868. http: / / repositorio.casadelacultura.gob.ec/handle/34000/1223. 
compilador "Estudio sobre los Cantares del Pueblo Ecuatoriano". En Antología Ecuatoriana. Cantares del Pueblo Ecuatoriano, edición hecha por orden y bajo el auspicio de la Academia Ecuatoriana. Quito: Imprenta de la Universidad Central del Ecuador, 1892, I-XXVI, http://bdh-rd.bne.es/viewer. vm?id=0000044217\&page $=1$.

Montalvo Bustos, Yolanda. “Mera y sor Juana Inés de la Cruz". En Juan León Mera. Una visión actual, editado por Julio Pazos Barrera, 69-89. Quito: Pontificia Universidad Católica del Ecuador / Universidad Andina Simón Bolívar, Sede Ecuador / Corporación Editora Nacional, 1994.

Muratorio, Blanca. “Nación, identidad y etnicidad: imágenes de los indios ecuatorianos y sus imagineros a fines del siglo XIX". En Imágenes e imagineros. Representaciones de los indígenas ecuatorianos, siglos XIX y XX, editado por Blanca Muratorio, 109-196. Quito: FLACSO Ecuador, 1994.

Paladines, Carlos. Sentido y trayectoria del pensamiento ecuatoriano. Quito: Banco Central del Ecuador, 1990.

Pallares Arteta, Leonidas. "Discurso leído por el Señor Don Leonidas Pallares Arteta la noche del 15 del presente en el concierto de 'La Sociedad Filarmónica' ". Quito: Imprenta del Gobierno, 1884. http:/ / repositorio.casadelacultura.gob. ec/ bitstream/34000/18026/2/LBNCCE-msc06-Palleres-6800.pdf.

Pensamiento estético ecuatoriano. Estudio introductorio y selección de Daniel Prieto Castillo. Quito: Banco Central del Ecuador / Corporación Editora Nacional, 1986.

Pensamiento romántico ecuatoriano. Estudio introductorio y selección de Rodolfo Agoglia, 2. ${ }^{a}$ ed. Quito: Banco Central del Ecuador / Corporación Editora Nacional, 1988.

Pesántez, Catalina León. Hispanoamérica y sus paradojas en el ideario filosófico de Juan León Mera. Quito: Universidad Andina Simón Bolívar, Sede Ecuador / AbyaYala / Corporación Editora Nacional, 2011.

Rolando, Carlos A. Don Juan León Mera 1832-1932. Guayaquil: Imprenta i Talleres Municipales, 1932. http:// repositorio.flacsoandes.edu.ec/bitstream/10469/12547/2 / FBNCCE-Rolando-6918-PUBCOM.pdf.

Sáenz Andrade, Bruno. "La literatura en el período". En Historia de las literaturas del Ecuador. Literatura de la República, 1830-1895, coordinado por Diego Araujo Sánchez, 71-90. Quito: Universidad Andina Simón Bolívar, Sede Ecuador / Corporación Editora Nacional, 2002.

Vázquez, Honorato, "Sobre el carácter nacional de la poesía". Revista Ecuatoriana. T. II, n. ${ }^{\circ} 15$ (marzo 1890): 102-115.

Vega y Vega, Wilson. "Corpus bibliográfico de don Juan León Mera”. En Juan León Mera. Una visión actual, editado por Julio Pazos Barrera, 163-178. Quito: Pontificia Universidad Católica del Ecuador / Universidad Andina Simón Bolívar, Sede Ecuador / Corporación Editora Nacional, 1994.

Vera, José, “Bibliografía de Juan León Mera”. En Juan León Mera, antología esencial. Estudio introductorio, selección de textos, notas y edición de Xavier Michelena, 405-427. Quito: Banco Central del Ecuador / Abya-Yala, 1994. 